\title{
Detection and infectivity of SARS-CoV-2 in exhumated corpses
}

\author{
S. Plenzig ${ }^{1} \cdot$ F. Holz ${ }^{1}$ - D. Bojkova ${ }^{2} \cdot$ M. Kettner ${ }^{1} \cdot$ J. Cinatl ${ }^{2} \cdot$ M. A. Verhoff ${ }^{1} \cdot$ C. G. Birngruber ${ }^{1} \cdot$ S. Ciesek $k^{2,3,4}$. \\ H. F. Rabenau ${ }^{2}$
}

Received: 6 June 2021 / Accepted: 13 July 2021 / Published online: 24 July 2021

(c) The Author(s) 2021

\begin{abstract}
Postmortem detection of severe acute respiratory syndrome coronavirus type 2 (SARS-CoV-2) after the exhumation of a corpse can become important, e.g. in the case of subsequent medical malpractice allegations. To date, data on possible detection periods [e.g. by reverse transcription polymerase chain reaction (RT-PCR)] or on the potential infectivity of the virus after an exhumation are rare. In the present study, these parameters were examined in two cases with a time span of approximately 4 months between day of death and exhumation. Using SARS-CoV-2 RT-PCR on swabs of both lungs and the oropharynx detection was possible with cycle threshold $\left(C_{t}\right)$ values of about 30 despite signs of beginning decay. RTPCR testing of perioral and perinasal swabs and swabs collected from the inside of the body bag, taken to estimate the risk of infection of those involved in the exhumation, was negative. Cell culture-based infectivity testing was negative for both, lung and oropharyngeal swabs. In one case, RT-PCR testing at the day of death of an oropharyngeal swab showed almost identical $\mathrm{C}_{\mathrm{t}}$ values as postmortem testing of an oropharyngeal swab, impressively demonstrating the stability of viral RNA in the intact corpse. However, favorable climatic conditions in the grave have to be taken into account, as it was wintertime with constant low temperatures. Nevertheless, it was possible to demonstrate successful postmortem detection of SARSCoV-2 infection following exhumation even after months in an earth grave.
\end{abstract}

Keywords COVID-19 $\cdot$ Autopsy $\cdot$ RT-PCR-detection $\cdot$ Cell culture

\section{Introduction}

A question frequently encountered by medicolegal experts in the context of an impending exhumation of a corpse pertains to the odds of a positive outcome of a specific detection method in a given scenario [1]. In the past, numerous studies have been conducted to elucidate relevant factors influencing the pace of the decay process in an earth grave, whereby in

$\triangle$ S. Plenzig

plenzig@med.uni-frankfurt.de

1 Institute of Legal Medicine, Goethe University, University Hospital Frankfurt, Kennedyallee 104, 60596 Frankfurt am Main, Germany

2 Institute of Medical Virology, Goethe University, University Hospital Frankfurt, Paul-Ehrlich-Straße 40, 60596 Frankfurt am Main, Germany

3 German Centre for Infection Research, External Partner Site, 60323 Frankfurt am Main, Germany

4 Branch Translational Medicine and Pharmacology, Fraunhofer Institute for Molecular Biology and Applied Ecology (IME), 60596 Frankfurt am Main, Germany addition to ambient temperature (season), e.g. soil conditions and clothing of the corpse, have been examined [2,3]. Reasons for an exhumation include, among others, charges filed for suspected homicides, cases pursuant to insurance law, and medical malpractice allegations $[4,5]$. Existing data on the detection of bacteria or viruses in exhumed corpses are rather scarce, but may play a crucial role, for example concerning allegations regarding hygiene standards. Breitmeier et al. reported successful detection of Salmonella enteritidis after a postmortem interval (PMI) of 17 days and of influenza A after a PMI of 1.2 months in their exhumation study [2]. In the context of the current coronavirus disease 2019 (COVID-19) pandemic with an enormous death toll in the general population, a case scenario with the necessity to assess detection possibilities of severe acute respiratory syndrome coronavirus type 2 (SARS-CoV-2) after exhumation was expectable. In addition to detection of the virus in bodily fluids and organs, the question arises as to whether a corpse or its environment (coffin, body bag) are infectious after exhumation. SARS-CoV-2 was already detected by reverse transcription polymerase chain reaction (RT-PCR) 
on the body surface and the vicinity of cadavers, subsequent tests in the cell culture were negative [6]. In the present study, detection of SARS-CoV-2-RNA by RT-PCR and cell culture-based infectivity testing of the virus were examined in cases of exhumed decedents who died of COVID-19.

\section{Material and methods}

\section{Exhumation}

In April, two corpses of deceased persons, who supposedly died of COVID-19, were exhumed at the order of the public prosecutor. In the first case, exhumation was ordered to confirm a SARS-CoV-2 infection, which had antemortem been proven by SARS-CoV-2 RT-PCR. In the second case, the patient had been tested positive for SARS-CoV-2 prior to his demise only by an antigen rapid test. Subsequent medicolegal autopsy and the following additional examinations were ordered to confirm or reject SARS-CoV-2 infection and consecutive COVID-19 as the cause of death and to assess possible competing causes of death.

\section{Medicolegal autopsy, histological and toxicological examinations}

Immediately after the exhumation, both corpses were transferred to the Institute of Legal Medicine, where a full medicolegal autopsy was carried out. In the course of both autopsies, swabs were collected at identical sites from both lungs, pleural effusion, oropharynx, perioral and perinasal regions, and the inside of the body bag at head level (an overview of the post mortem swabbing sites can also be found in Table 2). The latter three of the swabs were taken to assess a possible risk of infection for those involved in the handling of the body (e.g., morticians).

For the acquisition of the lung swabs, care was taken to avoid contamination during the process. The organ surface was $1 \times$ disinfected with Octenisept ${ }^{\circledR}$ (Schülke \& Mayr $\mathrm{GmbH}$, Norderstedt, Germany) with a drying time of $1 \mathrm{~min}$ followed by incision of the visceral pleura with a sterile scalpel. For toxicological examination, femoral venous blood, cardiac blood, bile, urine (only in case 2), small tissue samples of brain, lung, liver, and kidney as well as hair were collected and analyzed using gas chromatography and highperformance liquid chromatography mass spectrometry.

For histological examinations, samples of the heart, lungs, liver, spleen, pancreas, kidneys, adrenal glands, thyroid gland as well as paratracheal lymph nodes were taken, fixed in $4.5 \%$ formalin solution, processed according to standard protocols and stained for hematoxylin and eosin. In both cases, the brain tissue was in a liquefied state, so no evidence could be obtained for histological examinations.

\section{SARS-CoV-2 RT-PCR}

Swabs were suspended in $2 \mathrm{~mL}$ of phosphate-buffered saline (PBS) and incubated for $5 \mathrm{~min}$ suspended in $2 \mathrm{~mL}$ phosphate buffered saline (PBS) of which $500 \mu \mathrm{L}$ was examined by RTPCR. A total of $500 \mu \mathrm{L}$ of the swab dilution was mixed with PCR lysis buffer (1:1 ratio) then transferred to barcoded tubes and subjected to rRT-PCR-analysis on the Cobas 6800 system (Roche Diagnostics International AG, Rotkreuz, Switzerland). The Cobas SARS-CoV-2 master mix was supplemented with an internal RNA control and primer-probe set targeting ORF1 and E-gene according to the manufacturer's protocol. SARS-CoV-2 RT-PCR was performed according to the manufacturer's recommendations. Positive results were reported as semi-quantitative $C_{t}$ values. In addition, three quantitative comparison samples containing $10^{5}, 10^{6}$, and $10^{7}$ SARSCoV-2 (BetaCoV/Munich/ChVir984/2020) RNA copies/mL were used to generate a 3-point standard curve and to calculate viral RNA copies $/ \mathrm{mL}$ [7]. The comparison samples were provided by INSTAND e.V. (Düsseldorf, Germany). In case 1, an RT-PCR test result of a swab collected on the day of death was available. Here, the cobas ${ }^{\circledR} 8800$ platform had been used with the same reagents used for testing the postmortem samples.

No tests were carried out for SARS-CoV-2 variants of concern (VOC) or other viruses as these were not relevant at the time of examination.

\section{SARS-CoV-2 infectivity test using cell culture}

Positive samples from the initial RT-PCR were used for cell culture experiments. Here $500 \mu \mathrm{L}$ of the swab dilution was mixed with $2 \mathrm{~mL}$ of cell culture medium [minimal essential medium (MEM) containing 1\% FCS (Sigma-Aldrich; St. Louis, MO, USA), 3\% amphotericin B and 0.2\% Primocin (InvivoGen; San Diego, CA, USA)]. These mixtures were immediately transferred to Caco-2 cells (human colon carcinoma cells, obtained from DSMZ, Braunschweig, Germany, no.: ACC 169) seeded in 5.5 $\mathrm{cm}^{2}$ culture tubes. Cells were incubated in a $\mathrm{CO}_{2}$-incubator at $37^{\circ} \mathrm{C}$ for up to seven days and assessed microscopically every day for virus specific cytopathogenic effects (CPE) [12, 14]. After seven days or earlier in the case of cell lysis occurred as a sign of cell culture infection by the added virus, cell culture supernatants were tested for the presence and amount of viral RNA by RT-PCR using cobas ${ }^{\circledR}$ SARS-CoV-2 (Roche Diagnostics), to verify that $\mathrm{CPE}$ were attributable to SARS-CoV-2 infection.

\section{Results}

\section{Exhumation}

Both corpses had been put into closed plastic body bags and then buried in a wooden coffin (with burial depth of $120 \mathrm{~cm}$, 
Table 1 Age and gender of the deceased, pre-existing conditions, time span between death and exhumation, and burial depth (measured from surface to the top of the coffin lid)

\begin{tabular}{|c|c|c|c|c|c|}
\hline Case & Gender & Age/y & Pre-existing conditions & $\begin{array}{l}\text { Time span death to } \\
\text { exhumation/d }\end{array}$ & $\begin{array}{l}\text { Burial } \\
\text { depth/ } \\
\mathrm{cm}\end{array}$ \\
\hline 1 & $\mathrm{f}$ & $>90$ & $\begin{array}{l}\text { Dementia, chronic renal insufficiency, arterial } \\
\text { hypertension, peripheral artery disease }\end{array}$ & 4 mo $0 \mathrm{~d}$ & 120 \\
\hline 2 & $\mathrm{f}$ & $>80$ & dementia, arterial hypertension, epilepsy & $3 \mathrm{mo} 26 \mathrm{~d}$ & 120 \\
\hline
\end{tabular}

Table 1). Upon exhumation both coffin lids showed partial collapses with still undamaged body bags. The external state of preservation of the body differed in that in case 1 , signs of decay as could be expected in a humid environment (in particular, skin loosening/slippage, moderate tissue softening), whereas in case 2 , a distinct mold infestation of the face was found. Both corpses were vested with a nightdress. In both cases, no signs of preservation measures were found.

\section{Medical history}

In case 1 , the woman had died 4 months before exhumation. The funeral took place 8 days after her death. Her medical records stated that she had suffered from dementia, chronic renal insufficiency, arterial hypertension, and peripheral artery disease. Thirteen days prior to death, she had been tested positive using a rapid SARS-CoV-2 antigen test, after initial symptoms of fever and fatigue had been noted 15 days prior to death (Table 2). One day before her death, the woman was admitted to a hospital in a state of strong dyspnea. Upon arrival, she was resuscitated but died a few hours later. A SARS-CoV-2 RT-PCR test of an oropharyngeal swab on the date of her death showed a $C_{t}$ value of 30.19 (ORF1 gene).

In case 2 , the woman had died 3 months and 26 days before exhumation. In her medical records, dementia, arterial hypertension, and epilepsy were listed as chronic pre-existing conditions. A rapid SARS-CoV-2 antigen test conducted 17 days before the death was positive, after she had displayed fever as an initial symptom 19 days prior to death (Table 2). A PCR test was not performed during her lifetime. In this case, there was no admission to a hospital in the course of the disease. The woman was buried 5 days after her death.

\section{Medicolegal autopsy, histological and toxicological examinations}

Upon medicolegal autopsy, both corpses showed moderate to advanced signs of external and mild to moderate signs

Table 2 Results of postmortem virological examinations and data on medical history of both cases; no cell culture was assessed in case of a negative RT-PCR result. $R T$-PCR, reverse transcription polymerase chain reaction; $C P E$, cytopathogenic effect; $C_{t}$, cycle threshold

\begin{tabular}{|c|c|c|c|c|c|c|}
\hline & \multicolumn{3}{|l|}{ Case 1} & \multicolumn{3}{|l|}{ Case 2} \\
\hline $\begin{array}{l}\text { Time span symptom } \\
\text { onset to death }\end{array}$ & \multicolumn{3}{|l|}{$15 \mathrm{~d}$} & \multicolumn{3}{|l|}{$19 \mathrm{~d}$} \\
\hline $\begin{array}{l}\text { Time span positive rapid } \\
\text { antigen test to death }\end{array}$ & \multicolumn{3}{|l|}{$13 \mathrm{~d}$} & \multicolumn{3}{|l|}{$17 \mathrm{~d}$} \\
\hline $\begin{array}{l}\text { Antemortem RT-PCR/ } \\
\mathrm{C}_{\mathrm{t}} \text {-value (ORF1 gene)/ } \\
\text { swab localization }\end{array}$ & \multicolumn{3}{|c|}{$\begin{array}{l}30.19 \\
(=43.745 \text { RNA copies/mL)/oropharynx }\end{array}$} & \multicolumn{3}{|l|}{ Not collected } \\
\hline Symptoms & \multicolumn{3}{|c|}{ Fever, fatigue, deterioration of general condition } & \multicolumn{3}{|c|}{ Fever, fatigue, diarrhea, flu-like symptoms } \\
\hline $\begin{array}{l}\text { Postmortem swab locali- } \\
\text { zation }\end{array}$ & $\begin{array}{l}\text { RT-PCR }\left(\mathrm{C}_{\mathrm{t}} \text {-value ORF1 }\right. \\
\text { gene) }\end{array}$ & RNA copies/mL & cell culture (CPE) & $\begin{array}{l}\text { RT-PCR } \\
\text { (C } \mathrm{C}_{\mathrm{t}} \text {-value } \\
\text { ORF1 gene) }\end{array}$ & RNA copies/mL & cell culture $(\mathrm{CPE})$ \\
\hline Oropharynx & 32.10 & 11.445 & Negative & 29.02 & 99.457 & Negative \\
\hline Right lung & 31.42 & 18.447 & Negative & 30.17 & 44.364 & Negative \\
\hline Left lung & 29.16 & 90.147 & Negative & 29.90 & 53.622 & Negative \\
\hline Pleural effusion & Negative & & Not examined & Negative & & Not examined \\
\hline Perioral/perinasal & Negative & & Not examined & Negative & & Not examined \\
\hline $\begin{array}{l}\text { Inner surface of body } \\
\text { bag }\end{array}$ & Negative & & Not examined & Negative & & Not examined \\
\hline
\end{tabular}


of internal decay. The lungs were particularly affected to a lesser degree upon macroscopical examination (Fig. 1).

In case 1 , both lungs showed a condensed and solidified state as in prolonged inflammation. Furthermore, all three main branches of the coronary arteries showed coronary heart disease while a general atherosclerosis and signs of renal atherosclerosis were noted. Examination of the heart yielded a mitral valve insufficiency and aortic valve stenosis.

In case 2, the lung tissue was intensely solidified and somewhat friable in the central parts of lobes as in prolonged inflammation. The heart showed left ventricular hypertrophy (wall of the left ventricle: $2.4 \mathrm{~cm}$; heart weight: $320 \mathrm{~g}$ ), coronary heart disease of the left anterior descending and circumflex, mitral valve insufficiency, and aortic valve stenosis. Upon further inspection, general atherosclerosis and signs of renal atherosclerosis were noted.

Histologically, lung affection of decay was more pronounced than expected based on macroscopical findings. There were accumulations of bacteria, partly blurred cell boundaries, cell shadows and sometimes unstained cell nuclei in all organs of both cases.

In case 1, interstitial accumulation of lymphocytes and, as far as it could be assessed in the presence of decay, a mild hemorrhagic edema and alveolar hyaline membranes as signs of an acute respiratory distress syndrome (ARDS) in its exudative phase were present. In addition, signs of moderate chronic obstructive pulmonary disease (COPD) were seen.

In case 2 , lungs displayed an intense intraalveolar edema, interstitial accumulations of lymphocytes, broadened alveolar septa, and numerous patchy accumulations of granulocytes. In addition, cardiac hypertrophy could be shown.

Postmortem toxicological analysis demonstrated the drugs fentanyl, midazolam, propofol, norephedrine and amantadine in case 1 (having gone through clinical resuscitation). Drug concentrations were subtherapeutic or therapeutic and thus did not indicate an intoxication. The blood alcohol concentration was $0.45 \%$, which may be attributed to endogenous ethanol production in the postmortem phase.
In case 2 , the drugs levetiracetam, fentanyl and bisoprolol were found to be of no relevance to death in terms of their concentration. The blood alcohol concentration was $0.08 \%$ and, as in case 1 , attributed to postmortem changes.

\section{Virological examinations}

Swabs collected from the oropharynx and lungs of both cases tested positive for SARS-CoV-2 in the RT-PCR with $C_{t}$ values ranging from 29.16 to 32.10 in case 1 and 29.02 to 30.17 in case 2 , respectively, whereas RNA copies $/ \mathrm{mL}$ ranged from 11.445 to 90.147 in case 1 and 44.364 to 99.457 in case 2 (Table 2). In case 1, 4 months after death, viral RNA copies in the oropharyngeal swab were reduced by a factor of approximately 3.8 as compared to the antemortem findings. In addition, PCR-positive samples were tested for infectivity in cell culture. None of the six samples showed a cytopathogenic effect after seven days, so there was no longer any measurable infectivity. The cell culture supernatants were subsequently tested for SARSCoV-2-RNA by RT-PCR and all showed a positive result, which reflects the inoculated sample material.

\section{Cause of death}

In both cases, COVID-19 pneumonia was ascertained as the cause of death. In case 2, COVID-19 pneumonia had been complicated by bacterial superinfection.

\section{Discussion}

In the medical literature, there are hardly any publications on the detection of viruses in exhumated corpses, in particular after a moderate postmortem interval. A comparable time span has been published for the detection of $\mathrm{HCV}$ RNA [8], whereas positive testing at an early point in time after burial has been shown for influenza (1.2 months [2])
Fig. 1 Macroscopical aspect of the lungs (left: case 1, right: case 2 - during the collection of samples for virological examinations)

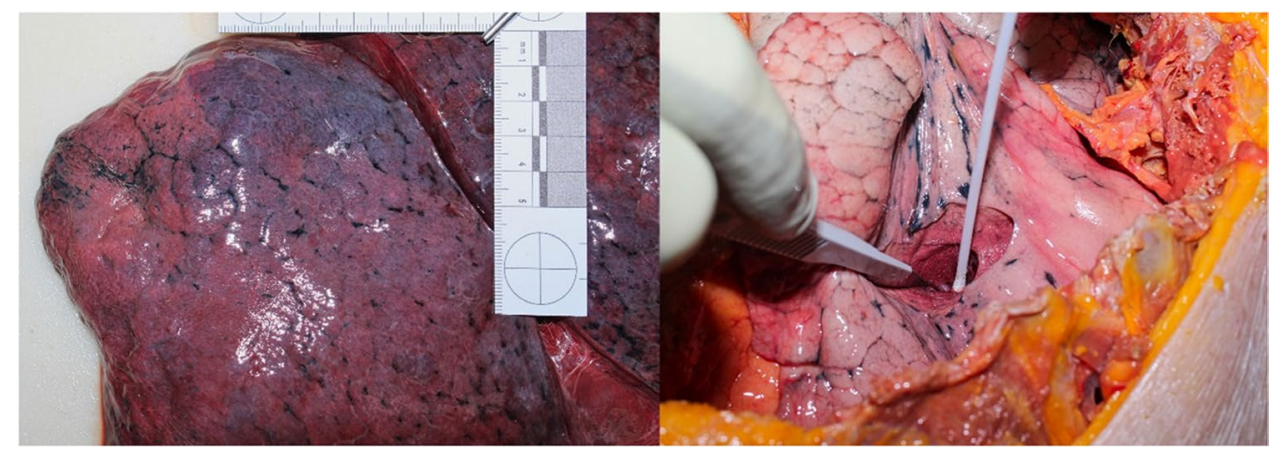


and recently for SARS-CoV-2, where RT-PCR testing showed positive results in lung and heart tissue of a case one month after death with $\mathrm{C}_{\mathrm{t}}$ values of 31 and 36 , respectively [9]. In their study, no infectivity could be detected by the use of cell culture [9]. Prasad et al. showed that SARS-CoV-2 could be detected by RT-PCR from a nasopharyngeal swab of an exhumed corpse 36 days after death and pointed out the high stability of the virus [10].

In the present study, detection of SARS-CoV-2 by RTPCR in lung and oropharyngeal swabs was possible in two cases after a time span of four months between death and exhumation. In addition, samples of the body surface and the environment of the body were tested to identify potential risks in the handling of the body during and after exhumation for involved personnel. Neither perioral nor perinasal skin swabs, nor those collected from the inside of the body bags, were positive in RT-PCR testing. In those samples with RT-PCR positive lung and oropharyngeal swabs, inoculated cell culture showed no cytopathogenic effect as an indicator of infectivity.

Despite these findings, a generalized assessment as noninfectious (of corpses in general or tissue and body fluid samples in particular) should not be derived from the results of our experiments. In clinical (living) patients, infectivity has been demonstrated up to 12 days after the onset of symptoms in the wild type virus [11]. In case 1 of our study, the first symptoms occurred 15 days and in case 2, 19 days before death, so it is possible that both patients were no longer infectious due to the duration of the disease at the time of death. Studies on postmortem changes in COVID19 patients have produced evidence that moderate signs of decay in a corpse will not have a major influence on the infectivity of the virus [12]. In their study with samples of living patients, La Scola et al. showed that infectivity in cell culture correlates with the level of viral RNA load, with CPE being observed at low $C_{t}$ values rather than at higher ones [13]. Also, Kohmer et al. were able to demonstrate that, using the same reagents and cell culture systems as in this study, only in $<15 \%$ of swab samples containing viral amounts of $<10^{5} \mathrm{RNA} / \mathrm{mL}$ infectivity was shown [14]. In our study, the RNA copy count/mL was always below $10^{5}$, so that a low viral RNA load can be assumed.

The postmortem detection of SARS-CoV-2 by RT-PCR was also successful in other studies after medium periods of time, for example 12 or 35 days after death $[15,16]$. A very peculiar finding presented in our study is that, an RT-PCR test result from the day of death was available, which, because the same test system was used, could be directly compared with the results of the postmortem oropharyngeal swab. When comparing the quantitative values, postmortem RNA copies $/ \mathrm{mL}$ were approximately 3.8 times lower as at the day of death. As a 3.8-fold decrease is within the normal fluctuation range of the test system used, the viral load may be assumed as rather stable in the intact body over a prolonged postmortem time.

In addition, our data show that postmortem SARS-CoV-2 RT-PCR testing can be successful not only in cases with initially low $\mathrm{C}_{\mathrm{t}}$-values $<25$, but also in cases, in which, at the time of death, there are moderate to lower virus quantities (with $\mathrm{C}_{\mathrm{t}}$-values $\sim 30$ or higher). In terms of the stability of SARS-CoV-2-RNA, soil temperature is likely to play a significant role. As it was winter, soil temperature should have been rather stable at around $8^{\circ} \mathrm{C}$ [17], likely to contribute to the successful testing as SARS-CoV-2 is known to have higher stability at lower temperatures [18].

This study is subject to some limitations. There were only two cases available to be included in the study, as the combination of exhumation and SARS-CoV-2 positivity is rare exhumations are rather seldomly performed in Germany (20 cases in our institute in the last 10 years) and SARS-CoV-2 with its first description in December 2019 [19] is to be regarded as a new virus. Although an advantage of the study may be seen in the fact that both cases had an almost identical time span spent in the earth grave and exhumations were performed almost contemporaneously in spring, rendering the results comparable as pertains to these circumstances, results may not be exported uncritically and employed for examinations elsewhere without regarding air and soil temperature conditions, and soil conditions in general.

\section{Conclusions}

RT-PCR-based detection of SARS-CoV-2 in corpses of COVID-19 patients is possible even after 4 months in an earth grave, when temperature and grave conditions are comparable to those in our study. Oropharyngeal as well as lung swabs yielded positive results and in the one case, where antemortem viral quantification had been performed, the viral load was shown to be rather stable as compared to postmortem material. None of the swabs testing positive for SARS-CoV-2 proved to be infectious as demonstrated by cell culture inoculation. These results should not be overinterpreted in the sense of a general non-infectious state of exhumated corpses having died from COVID-19, as inter alia both cases included in this study had time spans between initial symptoms and death of $\geq 15$ days.

Funding Open Access funding enabled and organized by Projekt DEAL.

\section{Declarations}

Ethics approval and consent to participate For this type of study, formal consent is not required. 
Conflict of interest The authors declare no competing interests.

Open Access This article is licensed under a Creative Commons Attribution 4.0 International License, which permits use, sharing, adaptation, distribution and reproduction in any medium or format, as long as you give appropriate credit to the original author(s) and the source, provide a link to the Creative Commons licence, and indicate if changes were made. The images or other third party material in this article are included in the article's Creative Commons licence, unless indicated otherwise in a credit line to the material. If material is not included in the article's Creative Commons licence and your intended use is not permitted by statutory regulation or exceeds the permitted use, you will need to obtain permission directly from the copyright holder. To view a copy of this licence, visit http://creativecommons.org/licenses/by/4.0/.

\section{References}

1. Althoff H (1974) Bei welchen Fragestellungen kann man aussagefähige pathomorphologische Befunde nach Exhumierung erwarten? Z Rechtsmed 75(1):1-20

2. Breitmeier D, Graefe-Kirci U, Albrecht K, Weber M, Tröger HD, Kleemann WJ (2005) Evaluation of the correlation between time corpses spent in in-ground graves and findings at exhumation. Forensic Sci Int 154(2-3):218-223

3. Schmidt W, Vock R (1986) Die Exhumierung: Praktisches Vorgehen und Asservierung. Präparator 32:337-342

4. Karger B, Lorin de la Grandmaison G, Bajanowski T, Brinkmann B (2004) Analysis of 155 consecutive forensic exhumations with emphasis on undetected homicides. Int J Legal Med 118(2):90-94

5. Stachetzki U, Verhoff MA, Ulm K, Müller KM (2001) Morphologische Befunde und versicherungsmedizinische Aspekte bei 371 Exhumierungen. Pathologe 22(4):252-258

6. Schröder AS, Edler C, Ondruschka B, Püschel K, Schädler J, Heinemann A et al (2021) The handling of SARS-CoV-2 associated deaths - infectivity of the body. Forensic Sci Med Pathol. https://doi.org/10.1007/s12024-021-00379-9

7. Kohmer N, Rabenau HF, Hoehl S, Kortenbusch M, Ciesek S, Berger A (2021) Comparative analysis of point-of-care, highthroughput and laboratory-developed SARS-CoV-2 nucleic acid amplification tests (NATs). J Virol Methods 291:114102

8. McDermott J, Parisi SG, Martini I, Boldrin C, Franchin E, Dal Bello F et al (2019) Detection of hepatitis C virus in an exhumed body identified the origin of a nosocomial transmission that caused multiple fatal diseases. J Hosp Infect 102(3):332-336

9. Gabbrielli M, Gandolfo C, Anichini G, Candelori T, Benvenuti M, Savellini GG et al (2021) How long can SARS-CoV-2 persist in human corpses? Int J Infect Dis 106:1-2. https://doi.org/10. 1016/j.ijid.2021.03.052

10. Prasad M, Nachappa SA, Anand N, Rudresh DU, Singh Y, Gangani SP et al (2021) The detection of SARS-CoV-2 in autolysed samples from an exhumed decomposed body: implications to virus survival, genome stability and spatial distribution in tissues. medRxiv. https://doi.org/10.1101/2021.02.16.21251805. Preprint

11. Singanayagam A, Patel M, Charlett A, Lopez BJ, Saliba V, Ellis J et al (2020) Duration of infectiousness and correlation with RTPCR cycle threshold values in cases of COVID-19. England Euro Surveill 25(32):2001483

12. Plenzig S, Bojkova D, Held H, Berger A, Holz F, Cinatl J et al (2021) Infectivity of deceased COVID-19 patients. Int J Legal Med 5:1-6. https://doi.org/10.1007/s00414-021-02546-7

13. La Scola B, Le Bideau M, Andreani J, Hoang VT, Grimaldier C, Colson P et al (2020) Viral RNA load as determined by cell culture as a management tool for discharge of SARS-CoV-2 patients from infectious disease wards. Eur J Clin Microbiol Infect Dis 39(6):1059-1061

14. Kohmer N, Toptan T, Pallas C, Karaca O, Pfeiffer A, Westhaus S et al (2021) The comparative clinical performance of four SARS$\mathrm{CoV}-2$ rapid antigen tests and their correlation to infectivity in vitro. J Clin Med 10(2):328

15. Edler C, Schröder AS, Aepfelbacher M, Fitzek A, Heinemann A, Heinrich F et al (2020) Dying with SARS-CoV-2 infectionan autopsy study of the first consecutive 80 cases in Hamburg. Germany Int J Legal Med 134(4):1275-2128

16. Beltempo P, Curti SM, Maserati R, Gherardi M, Castelli M (2021) Persistence of SARS-CoV-2 RNA in post-mortem swab 35 days after death: a case report. Forensic Sci Int 319:110653

17. Deutscher Wetterdienst (DWD), station measurements of the soil temperature at a depth of $100 \mathrm{~cm}$ in C, https://cdc.dwd.de/portal/ 202102121428/mapview, accessed 2021-05-31

18. Matson M, Yinda C, Seifert SN, Bushmaker T, Fischer RJ, van Doremalen $\mathrm{N}$ et al (2020) Effect of environmental conditions on SARS-CoV-2 stability in human nasal mucus and sputum. Emerg Infect Dis 26(9):2276-2278

19. Lai CC, Shih TP, Ko WC, Tang HJ, Hsueh PR (2020) Severe acute respiratory syndrome coronavirus 2 (SARS-CoV-2) and coronavirus disease-2019 (COVID-19): the epidemic and the challenges. Int J Antimicrob Agents 55(3):105924

Publisher's Note Springer Nature remains neutral with regard to jurisdictional claims in published maps and institutional affiliations. 